\title{
Evaluation of the Acoustic Environment in a Protestant Church Based on Measurements of Acoustic Descriptors
}

\author{
Samuel Ansay, Paulo Henrique Trombetta Zannin \\ Laboratory of Environmental and Industrial Acoustics and Acoustic Comfort, Federal University of Paraná, Curitiba, Brazil \\ Email: paulo.zannin@pesquisador.cnpq.br
}

How to cite this paper: Ansay, S. and Zannin, P.H.T. (2016) Evaluation of the Acoustic Environment in a Protestant Church Based on Measurements of Acoustic Descriptors. Journal of Building Construction and Planning Research, 4, 172-189. http://dx.doi.org/10.4236/jbcpr.2016.43011

Received: June 20, 2016

Accepted: August 28, 2016

Published: September 1, 2016

Copyright $\odot 2016$ by authors and Scientific Research Publishing Inc. This work is licensed under the Creative Commons Attribution International License (CC BY 4.0).

http://creativecommons.org/licenses/by/4.0/

\begin{abstract}
The new guidelines of the Catholic Church are in line with the guidelines adopted by Protestant churches since the Reformation, unifying appreciation for the liturgical practices of preaching and congregational singing. These guidelines require that the room, in this case the church, provides appropriate acoustic characteristics, which can be characterized by acoustic descriptors such as Reverberation Time (RT), Clarity (C80) and Definition (D50). In this article, we analyzed the acoustic quality of a protestant church whose design tried to follow these guidelines. Our findings revealed the poor quality of the acoustic environment in terms of both speech intelligibility and music. These findings emphasized the need to adopt not only Reverberation Time but also other acoustic descriptors such as Clarity and Definition in church design.
\end{abstract}

\section{Keywords}

Acoustic Quality, Church, Clarity, Definition, Reverberation Time

\section{Introduction}

Architectural acoustics has helped churches to achieve their liturgical goals [1]-[3]. The church became a center for the proclamation of the gospel whose acoustics should meet people's needs [1]. The Protestant Reformation introduced congregational singing, and Martin Luther (Germany) and John Calvin (the Netherlands and Switzerland) found in music a way to hear the word of God and to praise and thank Him [4] [5].

The acoustics of a church must be appropriate for its worship service program. Three types of activities should be considered: 1) Preaching of the word from the rostrum or altar by the preacher; 2) Congregational singing by the faithful in the nave of the 
church; and 3) Musical performance by the church choir, organ or musical ensemble behind the altar or in the choir stalls [1]. These activities are often acoustically exclusive. However, to overcome these problems, Berardi [6] proposed the formulation of a parameter called "double synthetic index". Also, according to Berardi [6], "A double synthetic index has been defined to synthesize the acoustical properties related to the music and to the speech separately". Therefore, based on Berardi [6], one can probably find ways to manage the different acoustic requirements. A sanctuary optimized for speech intelligibility means sacrificing musical performances. The desired reverberation time (RT) of 2.5 to $3 \mathrm{~s}$ for a church with a pipe organ will reduce the intelligibility of the sermon [1]. The acoustics suitable for a choir is not the same as that for a preacher [1] [7] [8], but it will support and encourage the participation of the congregation [9]. Therefore, it is not acoustics that designs liturgical spaces; rather it is acoustics that must find ways to meet the liturgical requirements of the church [8]. The particularities of liturgies make churches acoustically complex environments that require responses and conditions that go beyond the solutions found for concert halls, opera houses and theatres [1] [10].

Assessments of the acoustic quality of a church involve two tasks: 1) Characterization of the acoustic space based on measurements of its acoustic properties, and 2) Comparison of the measured and optimal values for each liturgical event [7]. Because it is difficult to achieve such optimal values simultaneously, one condition must be prioritized at the expense of the others [1]. Three conditions for reverberant spaces are cited for Catholic churches, the most suitable one being the third condition: 1) Short reverberation time, which favors the speech intelligibility of the preacher; 2) Average reverberation time, which is useful for both music and speech intelligibility; and 3) A sufficiently long reverberation time to produce a resonant and glorious response of pipe organ music or choir singing [7] [8].

Jürgen Meyer [11], author of Church Acoustics (Kirchenakustik, in German), on pages 162 to 167 , offers three suggestions to reduce the reverberation time in churches. According to Meyer, as is known, most churches have stone slab floors, whose absorption coefficient is usually low. Meyer's [11] first suggestion is to: "Make a $10 \mathrm{~cm}$ deep hole under the chairs or pews and install a wooden floor in this cavity. The wooden floor must be flush with the stone floor". Table 1 shows the improvement in absorption coefficients for three types of floors, according to Meyer, page 163 [11]: 1) Smooth stone floor, 2) Wood floor set directly on the subfloor, and 3) Wooden floor set in the $10 \mathrm{~cm}$ deep cavity, flush with the level of the stone floor.

In his book Kirchenakustik, on page 167, Meyer's [11] second suggestion is to: "Install sound absorption material underneath the pews". The author recommends the use of mineral fiber or foam. His third suggestion is to upholster the pews. Table 2 shows the absorption coefficient of pews with and without upholstery.

In evangelical churches, speech intelligibility should generally be prioritized by a shorter reverberation time. However, in some churches, due to the emphasis given to praise and worship, or the use of a pipe organ or choir, a longer reverberation time or 
Table 1. Absorption coefficients of some types of floors, according to Meyer [11].

\begin{tabular}{ccccccc}
\hline Flooring material & $125 \mathrm{~Hz}$ & $250 \mathrm{~Hz}$ & $500 \mathrm{~Hz}$ & $1000 \mathrm{~Hz}$ & $2000 \mathrm{~Hz}$ & $4000 \mathrm{~Hz}$ \\
\hline Situation 1 & 0.01 & 0.01 & 0.02 & 0.02 & 0.03 & 0.03 \\
Situation 2 & 0.04 & 0.04 & 0.05 & 0.06 & 0.06 & 0.06 \\
Situation 3 & 0.15 & 0.12 & 0.10 & 0.07 & 0.06 & 0.06 \\
\hline
\end{tabular}

Table 2. Absorption coefficients of church seats (mean values), according to Meyer [11].

\begin{tabular}{ccccccc}
\hline $\begin{array}{c}\text { Church } \\
\text { Seats }\end{array}$ & $125 \mathrm{~Hz}$ & $250 \mathrm{~Hz}$ & $500 \mathrm{~Hz}$ & $1000 \mathrm{~Hz}$ & $2000 \mathrm{~Hz}$ & $4000 \mathrm{~Hz}$ \\
\hline $\begin{array}{c}\text { Non-upholstered } \\
\text { With 3 cm upholstery }\end{array}$ & 0.10 & 0.15 & 0.18 & 0.20 & 0.20 & 0.20 \\
\hline
\end{tabular}

values intermediate to the recommended ones should be adopted: 1) Readings and sermons require a reverberation time of less than $1 \mathrm{~s} ; 2$ ) Contemporary music requires a reverberation time of about $1.5 \mathrm{~s} ; 3$ ) Congregational singing requires a reverberation time of about $2 \mathrm{~s}$; and 4) A pipe organ requires a reverberation time of about $3 \mathrm{~s}$ [1] [7].

Given the increasing importance of Evangelical Churches in Brazil, a country whose population is mostly Catholic, the aim of this work was to analyze the acoustic environment of a new Evangelical Church, which is in its final stage of completion. To this end, measurements of the following acoustic descriptors were undertaken: Reverberation Time (T30), Clarity (C80), and Definition (D50). The growth of the evangelical church in Brazil is shown by the following data: in 1991 the evangelical church represented $9 \%$ of the population, with 13.7 million followers; in 2000 it represented $15.4 \%$ of the population, with 26.1 million followers. Today it has over 43 million followers, representing more than $22 \%$ of the population.

\section{Description of the Church under Analysis}

The aforementioned acoustic parameters were measured in the Abba Christian Fellowship Church in the city Curitiba (southern Brazil). This church has 2800 individual upholstered seats, $4 \mathrm{~mm}$ carpeting, $12.5 \mathrm{~mm}$ perforated acoustic ceiling panels, textured painted walls and a rostrum with wooden flooring. The church has a 4-way front cluster sound system, which was not used during the acoustic measurements. Figure 1 shows the external facade of the church, while Figure 2 shows the floor plan of the nave, rostrum and detail of the columns of the mezzanine. Figure 3 presents an overview of the nave seen from the mezzanine. Table 3 describes the main dimensions of the church, whose total volume is about $16,200 \mathrm{~m}^{3}$.

\section{Materials and Method}

According to Cirillo and Martellotta [7], to qualify a space acoustically requires measuring its acoustic properties. In this study, the acoustic parameters of Reverberation time (T30), Clarity (C80) and Definition (D50) were measured according to the guidelines of 
the standard ISO 3382-1:2009-Acoustics-Measurement of Reverberation Time-Part 1: Performance Spaces [12]. The measurements were taken using the following instruments: 1) Brüel \& Kjaer 4296 omnidirectional sound source; 2) Lab. Grüppen Lab 300 power amplifier; 3) Brüel \& Kjaer 2238 sound level meter; 4) DIRAC 3.1 software, using the sine sweep method; and 5) an RME Fireface 800 firewire audio interface circuit board. According to the ISO 3382-1: 2009 standard [12], these measurements require the use of one sound source in two different positions. Therefore, a sound source was placed in two different positions-F1 and F2-on the rostrum, symmetrical in relation to the center line of the church, as indicated in Figure 4 and Figure 5.

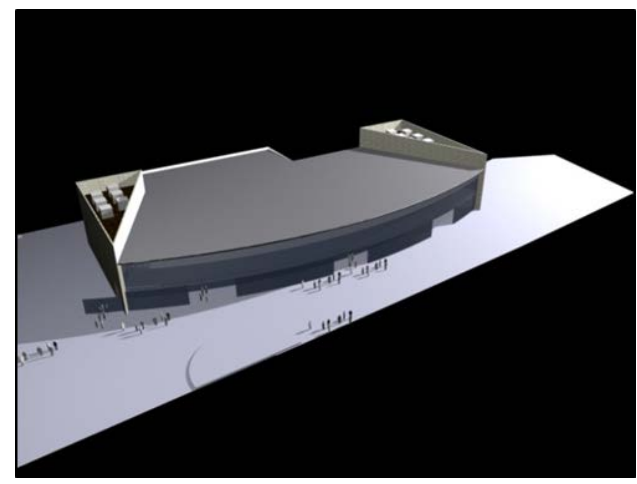

Figure 1. External view of the church.

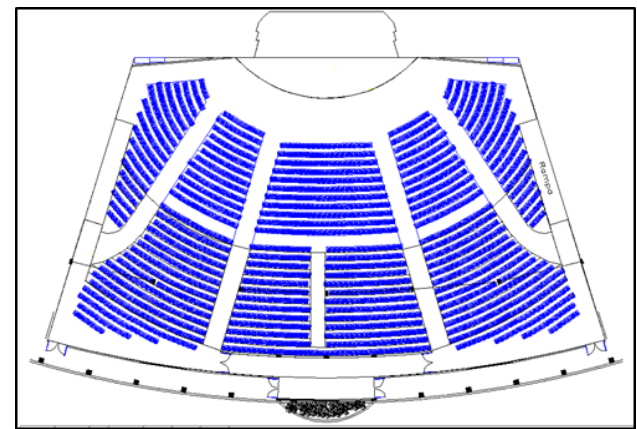

Figure 2. Floor plan of the nave and rostrum and detail of the columns supporting the mezzanine.

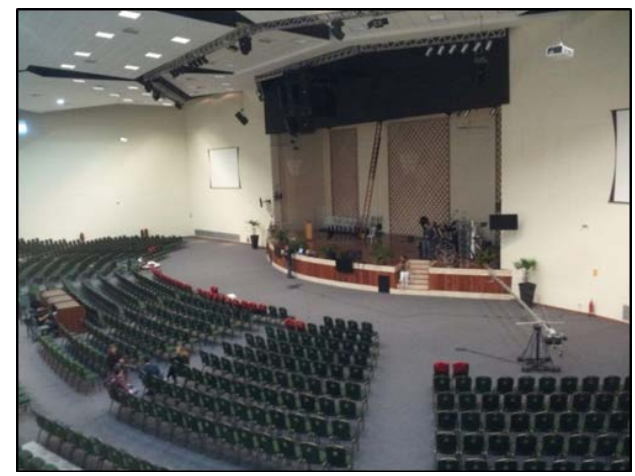

Figure 3. General view of the nave and rostrum. 
Table 3. Key internal dimensions of the church (in meters).

\begin{tabular}{cccc}
\hline \multirow{2}{*}{ Location in church } & \multicolumn{3}{c}{ Internal dimensions $(\mathrm{m})$} \\
\cline { 2 - 4 } & Width & Average height & Depth \\
\hline Rostrum & 15 & 9 & 5 \\
Frontofchurch & 40 & 11 & Distance to the rostrum \\
Middleofchurch & 50 & 10 & 0 \\
Front (Mezzanine) & 52 & $3.2-8.7$ & 15 \\
Back (Mezzanine, church) & 60 & $3.6-6.2$ & 30 \\
\hline
\end{tabular}

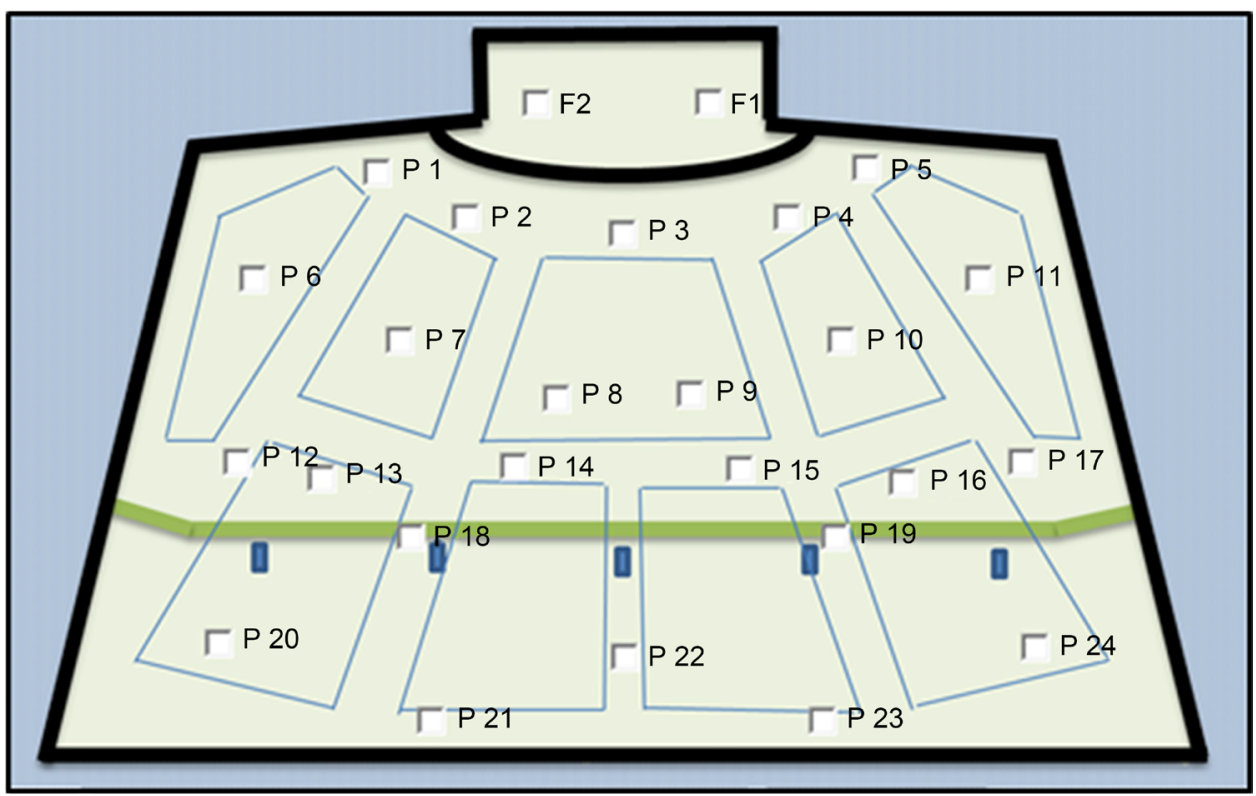

Figure 4. Location of the sound sources on the rostrum and receiver points on the ground floor.

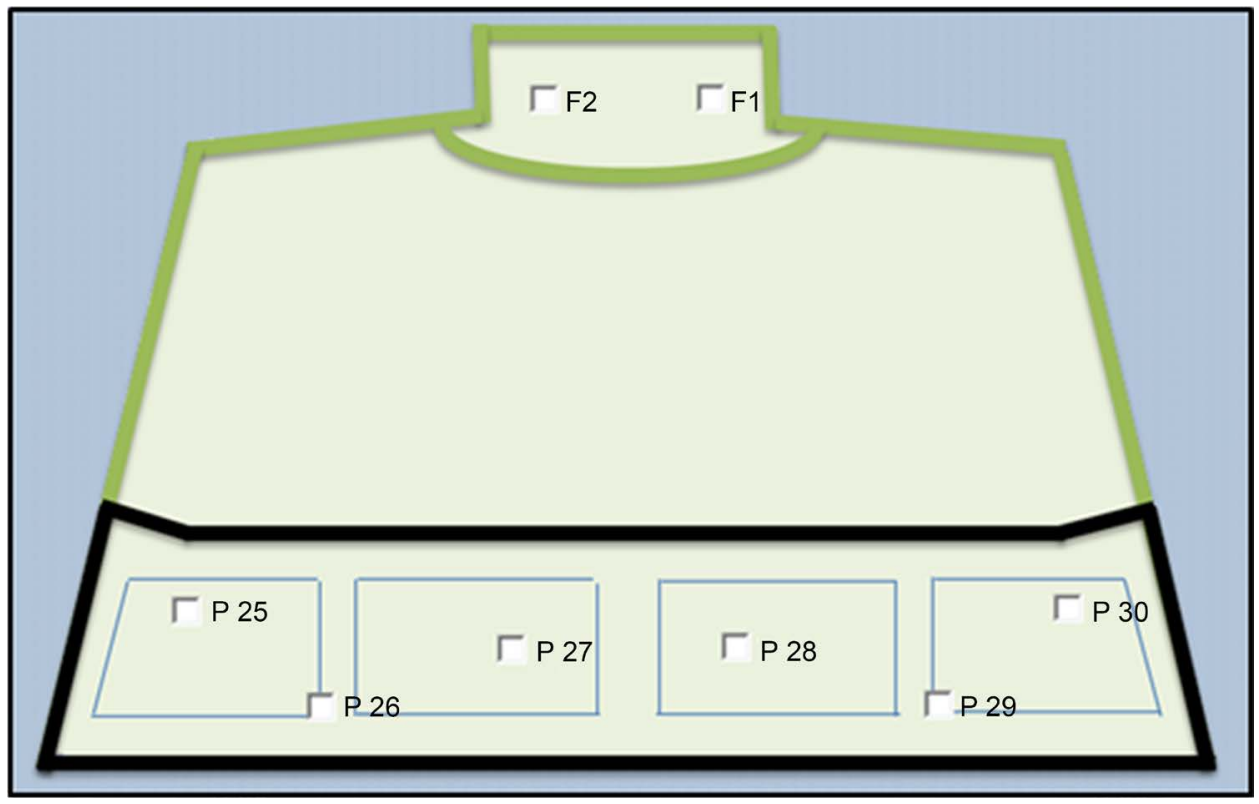

Figure 5. Location of the sound sources on the rostrum and receiver points on the mezzanine. 
Table 4 describes the distance between the receiver points and the positions of the sound source on the rostrum-position F1 and position F2. Measurements were taken at 30 receiver points, where the microphones were positioned at points representing the seats in the nave, at a height of $1.2 \mathrm{~m}$ from the floor, distributed as illustrated in Figure 6. The measurements were taken in the empty church without using the church's sound system.

Table 4. Distance, in meters, between the receivers points and the sound source positions on the rostrum (position 1 = F1) - (position 2 = F2).

\begin{tabular}{|c|c|c|}
\hline \multirow[t]{2}{*}{$\begin{array}{l}\text { Measuring point } \\
\text { (receivers) }\end{array}$} & \multicolumn{2}{|c|}{$\begin{array}{l}\text { Distance to the sound source in meters } \\
{[[\mathrm{m}]}\end{array}$} \\
\hline & $\mathrm{F} 1$ & F2 \\
\hline P1 & 17.73 & 8.04 \\
\hline P2 & 12.50 & 7.50 \\
\hline P3 & 9.43 & 9.43 \\
\hline P4 & 7.50 & 12.50 \\
\hline P5 & 8.04 & 17.73 \\
\hline P6 & 23.52 & 13.91 \\
\hline P7 & 18.87 & 11.66 \\
\hline P8 & 17.49 & 15.03 \\
\hline P9 & 15.03 & 17.49 \\
\hline P10 & 11.66 & 18.87 \\
\hline P11 & 13.91 & 23.52 \\
\hline P12 & 30.23 & 22.67 \\
\hline P13 & 29.73 & 23.32 \\
\hline P14 & 21.95 & 19.03 \\
\hline P15 & 19.03 & 21.95 \\
\hline $\mathrm{P} 16$ & 23.32 & 29.73 \\
\hline P17 & 22.67 & 30.23 \\
\hline P18 & 27.46 & 23.54 \\
\hline P19 & 23.54 & 27.46 \\
\hline P20 & 37.54 & 30.81 \\
\hline $\mathrm{P} 21$ & 32.65 & 24.43 \\
\hline $\mathrm{P} 22$ & 25,50 & 25.50 \\
\hline P23 & 24.43 & 32.65 \\
\hline P24 & 30.81 & 37.54 \\
\hline P25 & 36.43 & 29.11 \\
\hline P26 & 35.57 & 30.08 \\
\hline P27 & 27.38 & 24.28 \\
\hline P28 & 24.28 & 27.38 \\
\hline P29 & 30.08 & 35.57 \\
\hline P30 & 29.11 & 36.43 \\
\hline
\end{tabular}




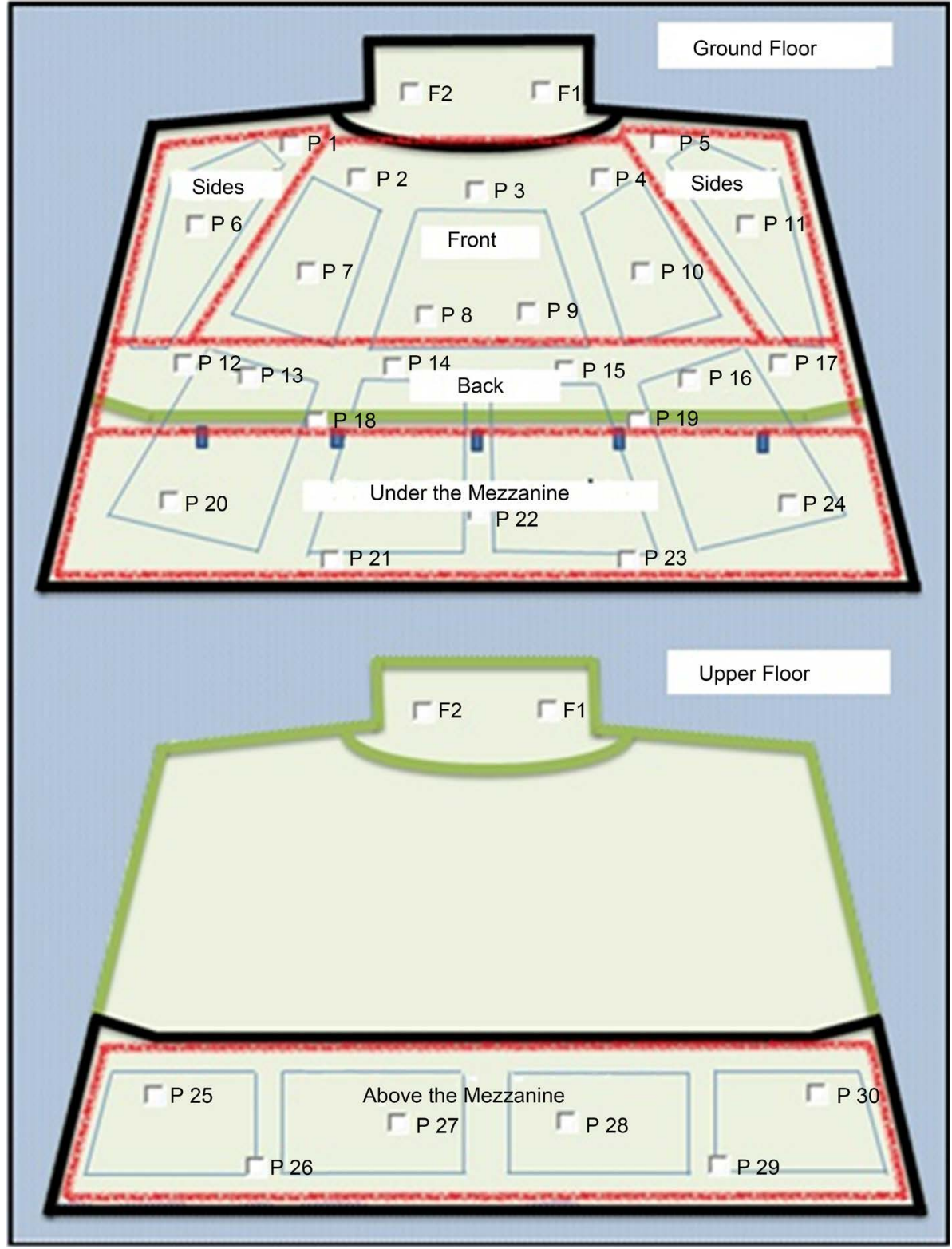

Figure 6. Division of the church's internal space into subareas-ground and upper floors.

The following parameters were investigated in this study: Reverberation Time (RT) according to Harris [13], and Clarity (C80) and Definition (D50) as described by Beranek [14] and Cirilo and Martellota [7]. The reference values for D50 and C80 used in this work are presented in Table 5 and Table 6, according to Marshall [15]. With regard to RT, the optimal time was obtained from the Brazilian standard NBR 12179: 1992-Acoustic Treatment in enclosed spaces [16]. For Protestant churches with a volume of $16,200 \mathrm{~m}^{3}$, this standard indicates an optimum RT of $1.8 \mathrm{~s}$.

\section{Results and Discussion}

The values of the parameters for each receiver point were measured in octave bands 
Table 5. Values for the parameter Clarity, C80, according to Marshall [15].

\begin{tabular}{cc}
\hline Clarity & C80 [dB] \\
\hline Pop rock & 7 to 18 \\
Opera & 3 to 7 \\
Symphony & -2 to 3 \\
Organ & -12 to -4 \\
\hline
\end{tabular}

Table 6. Values for the parameter Definition, D50, according to Marshall [15].

\begin{tabular}{cc}
\hline Definition & D50 [\%] \\
\hline Excellent & 0.86 to 1.0 \\
Very good & 0.67 to 0.86 \\
Good & 0.39 to 0.67 \\
Bad & 0.17 to 0.39 \\
Terrible & 0.06 to 0.17 \\
\hline
\end{tabular}

and the mean value was calculated from the arithmetic mean of the frequencies of 500, 1000 and $2000 \mathrm{~Hz}$ for the values of T30 and of D50, as recommended by Marshall [16]. The average value of C80 was obtained by the logarithmic mean of the frequencies of 500, 1000 and $2000 \mathrm{~Hz}$, as recommended by Marshall [15]. Table 7 lists the mean values of parameters C80, D50 and T30 at each receiver point.

The mean reverberation time was calculated to qualify the general environment of the church, as indicated in Table 8. As for the parameters of Clarity and Definition, it would not make sense to determine an average value for the general environment because these parameters are strongly dependent on the distance between the sound source and the receiver point [15]. However, for the analysis undertaken here, the space can be subdivided into areas that have the same acoustic or constructive characteristics, as illustrated in Figure 6. Table 8 lists the mean values of C80, D50 and T30 in each subarea of the church and shows a mean of T30 for the entire church.

In the Abba Christian Fellowship Church evaluated here, the church's music program for meetings follows the "Pop Rock" genre. According to Marshall [15], the C80 for this music genre lies within the range of 7 to $18 \mathrm{~dB}$.

Therefore, it should be clear in this part of this article that what is being studied here is C80 for an evangelical church that uses only the "Pop Rock" music genre.

Figure 7 illustrates the reverberation times, T30, as well as a logarithmic regression curve indicating the tendency of these values at each receiver point in relation to the distance from the sound source. Note that the points closest to the sound source present a slightly lower T30 than the more distant points, as indicated by the mean values listed in Table 4; the two points furthest from the regression line are located underneath the mezzanine. The mean reverberation time in this space is $\mathrm{T} 30=1.93 \mathrm{~s}$. 
Table 7. Measured values of the acoustic descriptors C80, D50 and T30.

\begin{tabular}{|c|c|c|c|}
\hline $\begin{array}{l}\text { Measuring points } \\
\text { (receivers) }\end{array}$ & Clarity C $80[\mathrm{~dB}]$ & Definiton D50 [\%] & $\mathrm{T} 30[\mathrm{~s}]$ \\
\hline $\mathrm{P} 1$ & -0.79 & 0.34 & 1.87 \\
\hline $\mathrm{P} 2$ & 0.56 & 0.42 & 1.86 \\
\hline P3 & 1.42 & 0.51 & 1.84 \\
\hline $\mathrm{P} 4$ & 0.56 & 0.42 & 1.86 \\
\hline P5 & -0.79 & 0.34 & 1.87 \\
\hline P6 & -0.94 & 0.34 & 1.92 \\
\hline P7 & 0.00 & 0.35 & 1.89 \\
\hline P8 & 0.80 & 0.48 & 1.92 \\
\hline P9 & 0.80 & 0.48 & 1.92 \\
\hline $\mathrm{P} 10$ & 0.00 & 0.35 & 1.89 \\
\hline P11 & -0.94 & 0.34 & 1.92 \\
\hline $\mathrm{P} 12$ & -0.93 & 0.33 & 1.94 \\
\hline P13 & -1.60 & 0.30 & 1.94 \\
\hline P14 & -0.77 & 0.35 & 1.94 \\
\hline $\mathrm{P} 15$ & -0.77 & 0.35 & 1.94 \\
\hline P16 & -1.60 & 0.30 & 1.94 \\
\hline P17 & -0.94 & 0.34 & 1.92 \\
\hline P18 & -0.69 & 0.32 & 1.91 \\
\hline P19 & -0.69 & 0.32 & 1.91 \\
\hline $\mathrm{P} 20$ & -1.41 & 0.30 & 1.97 \\
\hline $\mathrm{P} 21$ & -0.45 & 0.35 & 1.95 \\
\hline $\mathrm{P} 22$ & -1.38 & 0.27 & 2.02 \\
\hline $\mathrm{P} 23$ & -0.45 & 0.35 & 1.95 \\
\hline $\mathrm{P} 24$ & -1.41 & 0.30 & 1.97 \\
\hline $\mathrm{P} 25$ & -1.81 & 0.24 & 1.97 \\
\hline P26 & -1.50 & 0.29 & 1.97 \\
\hline P27 & -1.28 & 0.33 & 1.95 \\
\hline P28 & -1.28 & 0.33 & 1.95 \\
\hline P29 & -1.50 & 0.29 & 1.97 \\
\hline P30 & -1.81 & 0.24 & 1.97 \\
\hline
\end{tabular}

Table 8. Mean values of C80, D50 and T30 in each subarea of the church and mean T30 for the entire church.

\begin{tabular}{cccc}
\hline Sub area & C80 [dB] & D50 [\%] & RT30 [s] \\
\hline Front & 0.62 & 0.43 & 1.88 \\
Sides & -0.87 & 0.34 & 1.89 \\
Back & -0.98 & 0.33 & 1.90 \\
Under the Mezzanine & -1.00 & 0.32 & 1.97 \\
Above the Mezzanine & -1.53 & 0.28 & 1.96 \\
Average Reverberation & & - & 1.93 \\
Time (General indoor & - & & \\
environment) & &
\end{tabular}


Figure 8 shows the values of the parameter Definition D50, representing all the measured receiver points and a logarithmic regression line. As can be seen, the slightly downward inclination of the values of the farthest points on the regression curve indicates a tendency for lower speech intelligibility in the areas further away from the sound source.

With regard to the parameter Clarity, C80, for music, Figure 9 shows the receiver points, along with the logarithmic regression curve. Despite the wide distribution of the receiver points on the logarithmic regression curve, note that this curve clearly shows a strong tendency for the values of C80 to decline with distance. Figure 9 indicates that the mean values of C80 are much lower, than those required for the Pop Rock music genre used in the Abba Christian Fellowship Church. This is clearly indicated in Table 5 , which shows that the lowest value of $\mathrm{C} 80$ for Pop Rock is $7 \mathrm{~dB}$. The range of values found here would be adequate for symphonic music, see Table 5.

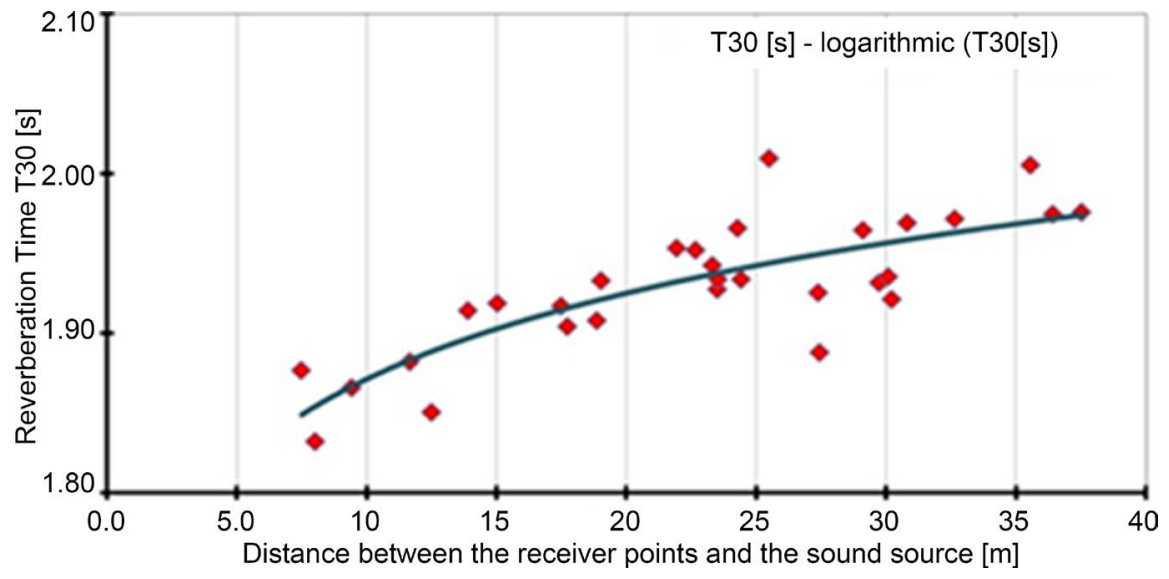

Figure 7. Reverberation Time T30 as a function of the distance $[\mathrm{m}]$ between the receiver points and the sound source.

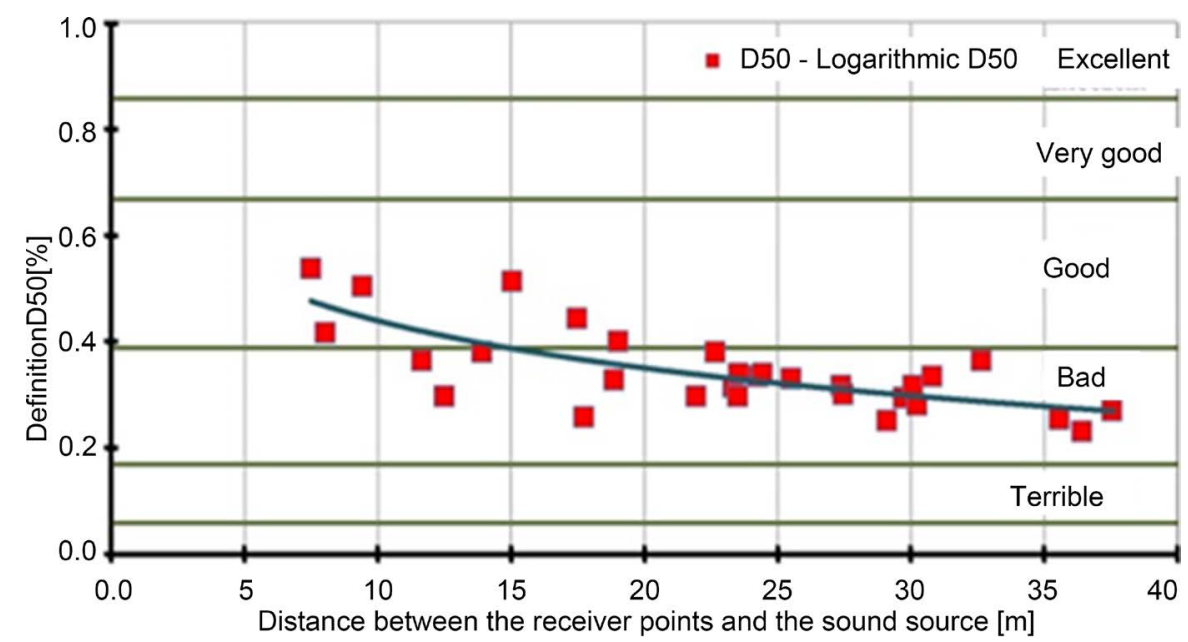

Figure 8. Distribution of the parameter Definition D50 [\%] as a function of the distance [m] between the receiver points and the sound source. The graph also indicates the ranges proposed by Marshall [15]. 
A detailed analysis of the parameters measured in each subarea indicates how the acoustic quality is distributed through environment. The subareas in question are identified as-FRONT, SIDES, BACK, UNDER THE MEZZANINE, and ABOVE THE MEZZANINE.

Figure 10 illustrates the distribution of D50 [\%] in the subarea FRONT as a function of the distance $[\mathrm{m}]$ between the receiver point in the nave and the sound source on the rostrum. The more frontal points possess a "Good" speech intelligibility, which declines to "Bad" at the points farther from the rostrum.

Figure 11 shows the distribution of $\mathrm{C} 80[\mathrm{~dB}]$ as a function of the distance between

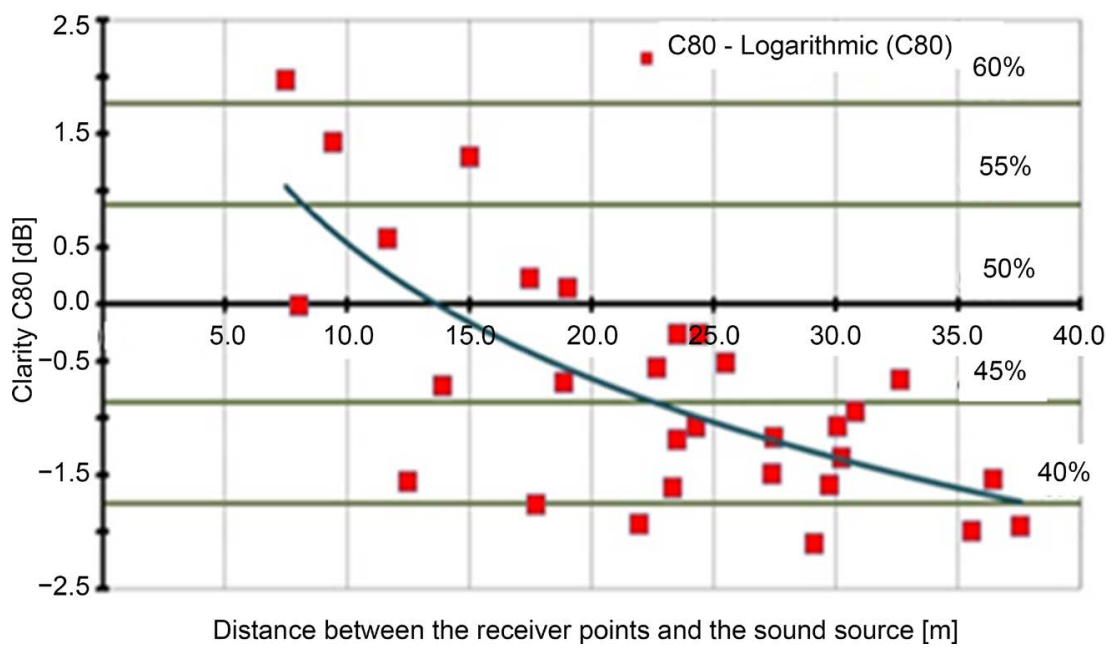

Figure 9. Distribution of the parameter Clarity C80 [dB] as a function of the distance $[\mathrm{m}]$ between the receiver points and the sound source.

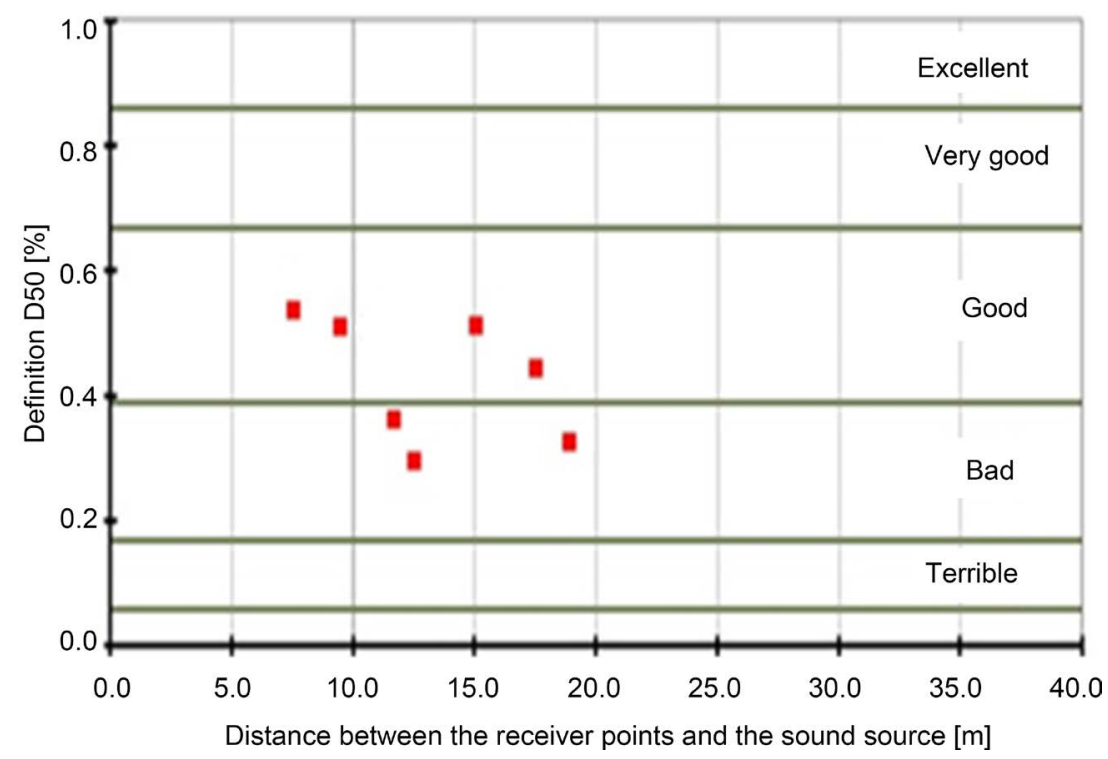

Figure 10. Distribution in the subarea FRONT of the parameter D50 [\%] as a function of the distance $[\mathrm{m}]$ between the receiver points and the sound source. The graph indicates the range of values proposed by Marshall [15]. 
the receiver (listener) and the sound source on the rostrum. All the receiver points fall outside the range of values indicated for the church's music program, i.e., Pop Rock. The range of values found would be ideal for the rendering of symphonic music, according to Table 5.

Figure 12 Illustrates the values for D50 [\%] for the subarea SIDES. Except for one measured point classified as "Good", all the other measured points lie within the range evaluated as "Bad". Figure 13 shows that for the points of C80, the subarea SIDES has values ranging from 0 to $-2 \mathrm{~dB}$. These values for C80 do not meet any of the music genre presented in Table 5. Figure 13 shows that for $\mathrm{C} 80$, the values of the points in the subarea SIDES lie within the range of 0 to $-2 \mathrm{~dB}$. These C 80 values do not satisfy any of the music genres listed in Table 5 .

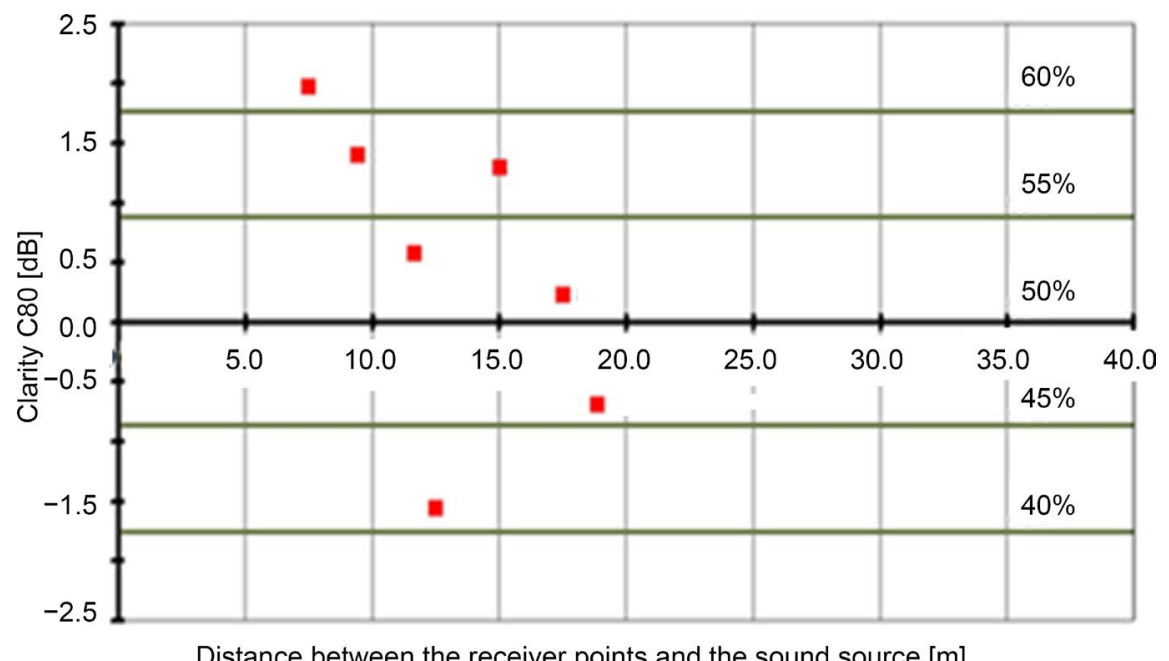

Figure 11. Distribution in the subarea FRONT of the parameter C80 [dB] as a functions of the distance between the receiver points and the sound source $[\mathrm{m}]$.

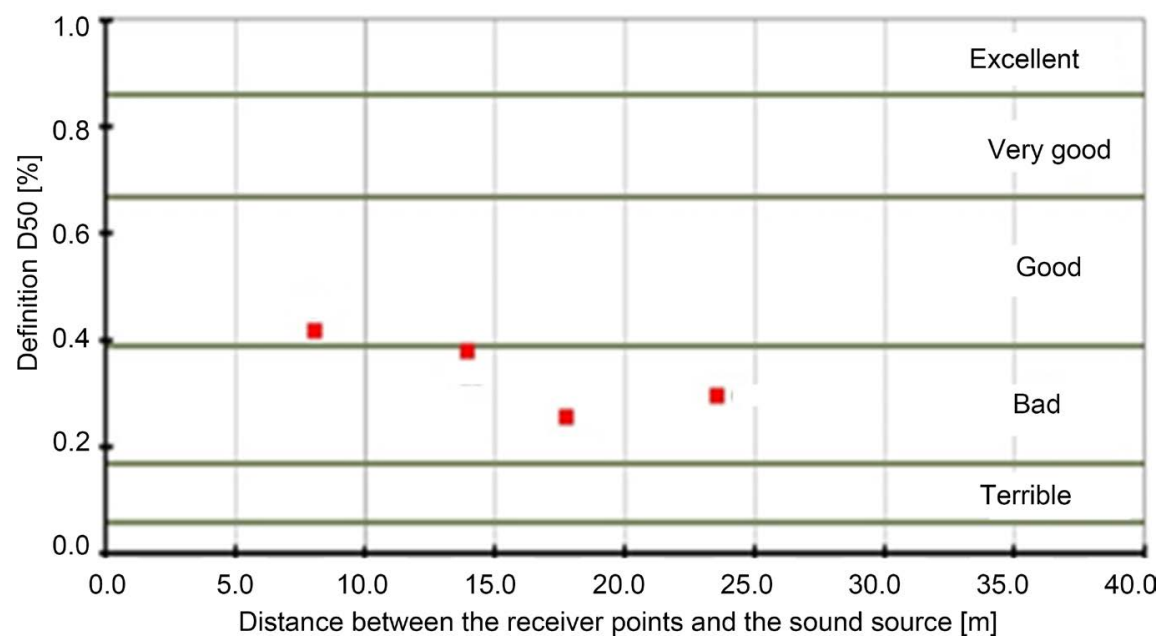

Figure 12. Distribution in the subarea SIDES of the parameter D50 [\%] as a function of the distance $[\mathrm{m}]$ between the receiver points and the sound source. The graph indicates the range of values proposed by Marshall [15]. 
Figure 14 illustrates the values of D50 and Figure 15 those for the C80 for the subarea BACK. Most of the receiver points lie within the "Bad" area for speech intelligibility, and also within intervals inadequate for the church's musical program.

Figure 16 illustrates the values of D50 and Figure 17 those of C80 for the subarea UNDER THE MEZZANINE. At the BACK of the church, the values of D50 all fall

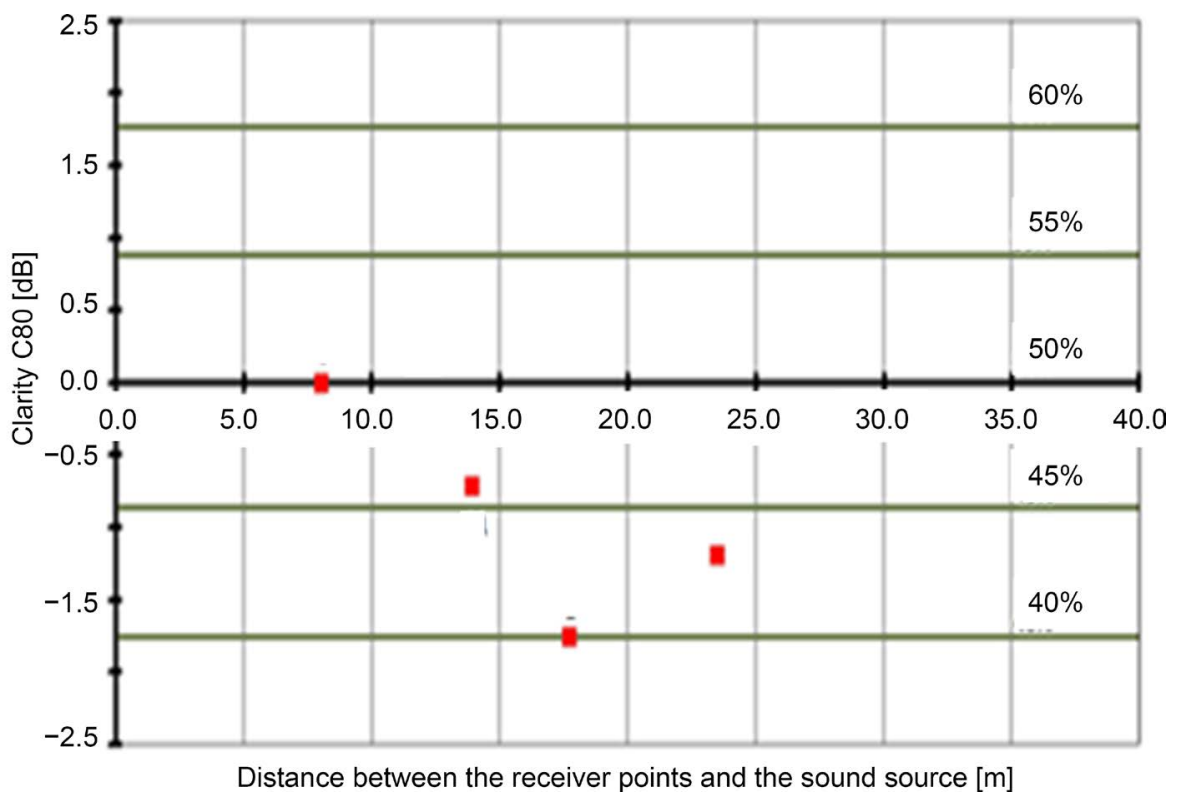

Figure 13. Distribution in the subarea SIDES of the parameter C80asa function of the distance between $[\mathrm{m}]$ the receiver points and the sound source.

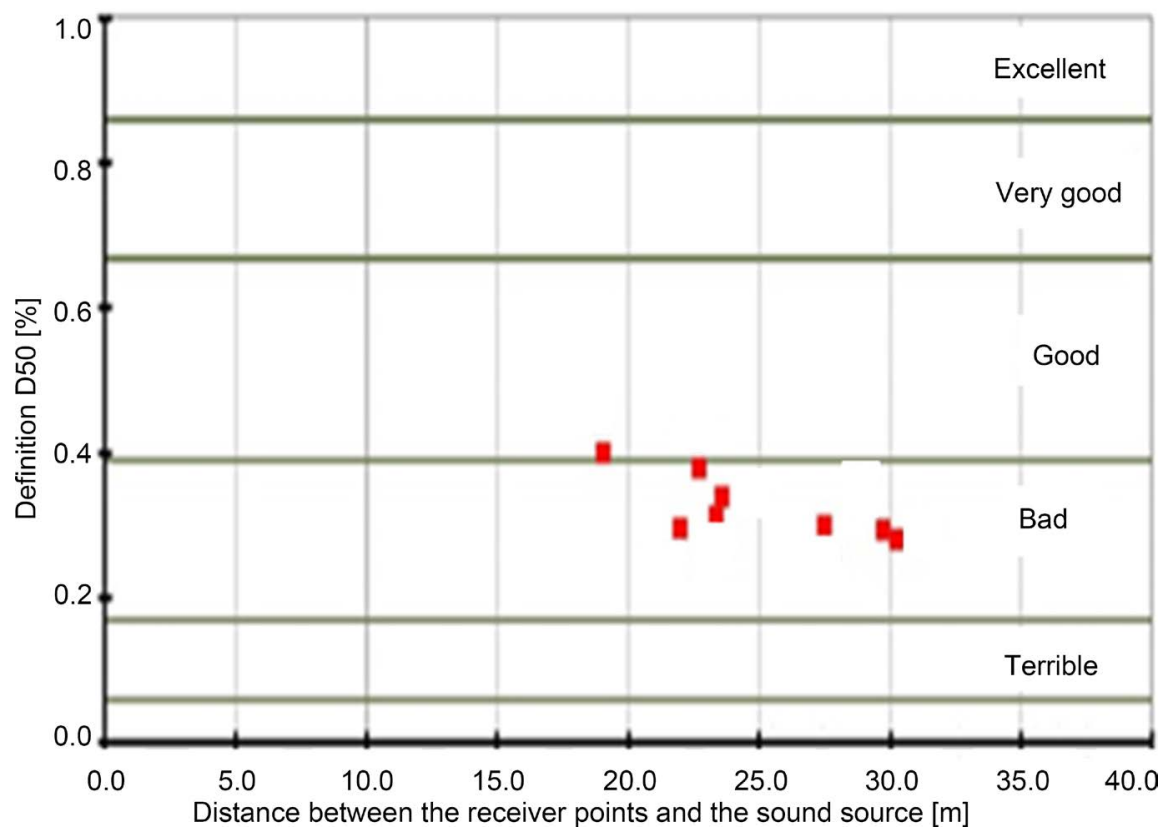

Figure 14. Distribution in the subarea BACK of the parameter D50 [\%] as a function of the distance $[\mathrm{m}]$ between the receiver points and the sound source. The graph indicates the range of values proposed by Marshall [15]. 


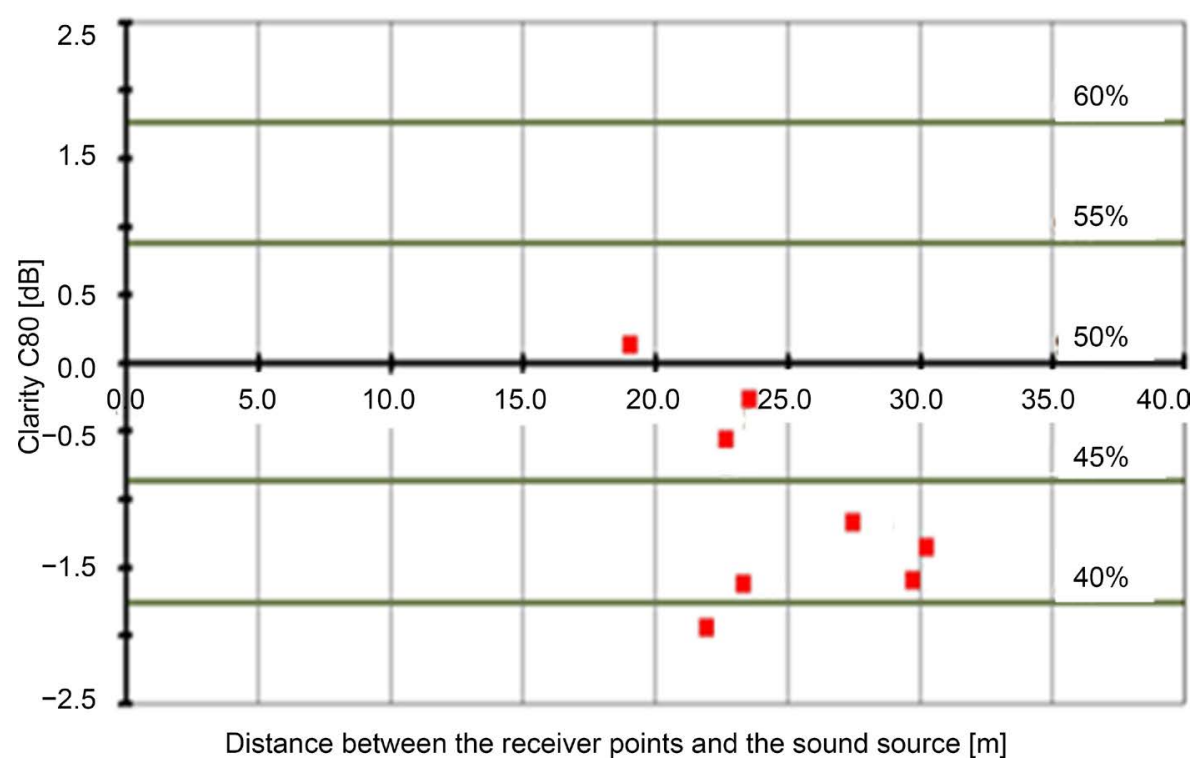

Figure 15. Distribution in the subarea BACK of the parameter C80 [dB] as a function of the distance $[\mathrm{m}]$ between the receiver points and the sound source.

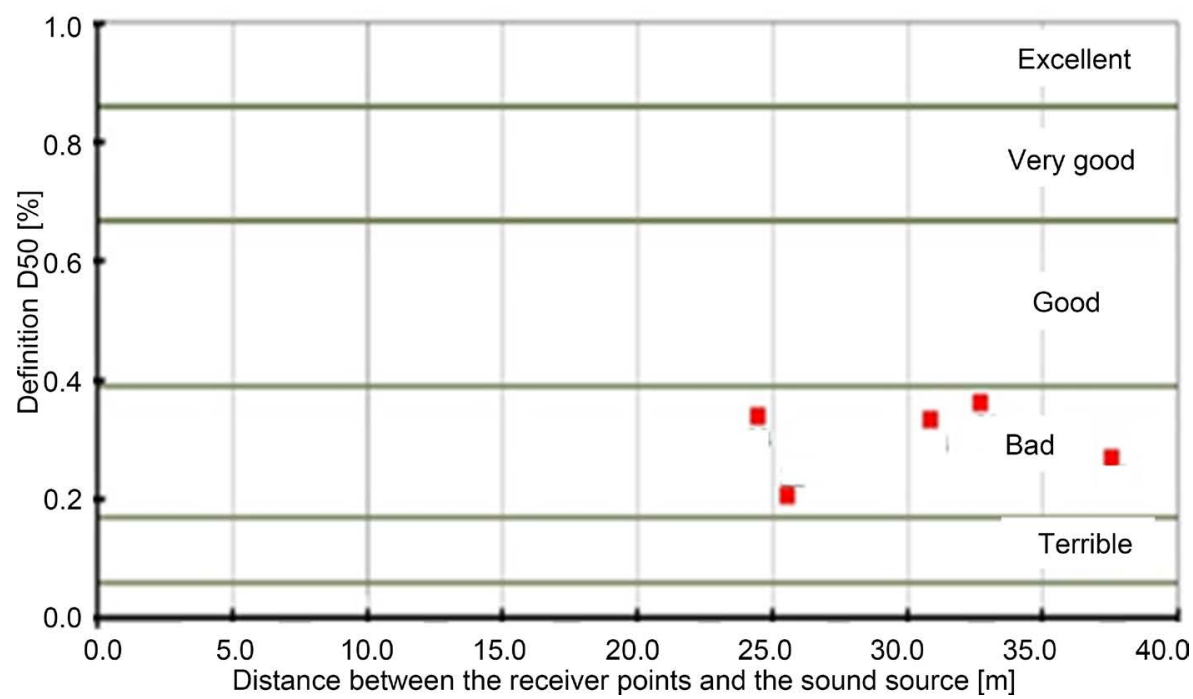

Figure 16. Distribution in the subarea UNDER THE MEZZANINE of the parameter D50 [\%] as a function of the distance $[\mathrm{m}]$ between the receiver points and the sound source. The graph indicates the range of values proposed by Marshall [15].

within the classification "Bad". The values of $\mathrm{C} 80$ range from 0 to $-2.5 \mathrm{~dB}$, and also do not satisfy the condition for the Pop Rock genre.

The subarea ABOVE THE MEZZANINE showed the worst values of Clarity (Figure 18), i.e., -1 to $-1.5 \mathrm{~dB}$, thus presenting undesirable values for $\mathrm{C} 80$, according to Table 5. All the values for Definition fall within the range of 0.2 to $0.4 \mathrm{~dB}$, i.e., within the range classified as "Bad," since all the points show values unacceptable for speech intelligibility (Figure 19).

Silva and Cabral's study [17] about sound pressure levels in Protestant churches in 
Brazil showed that these churches are very noisy, with sound systems reaching noise levels ranging from 96.5 to $99.5 \mathrm{~dB}$ (A). Noisy environments, contribute significantly to decay of speech intelligibility, which is characterized by the acoustic descriptor Definition D50 [\%], and by decay in the quality of musical performances, characterized by the acoustic parameter of Clarity, C80 [dB].

For Protestant churches and for the volume considered here, the Brazilian standard NBR 12,179 [16] recommends an optimal RT of $1.8 \mathrm{~s}$ for $\mathrm{V}=16,200 \mathrm{~m}^{3}$.

The average measured reverberation time was $1.93 \mathrm{~s}$. The analysis performed here indicates that although the RT designed for the church is adequate, in view of the

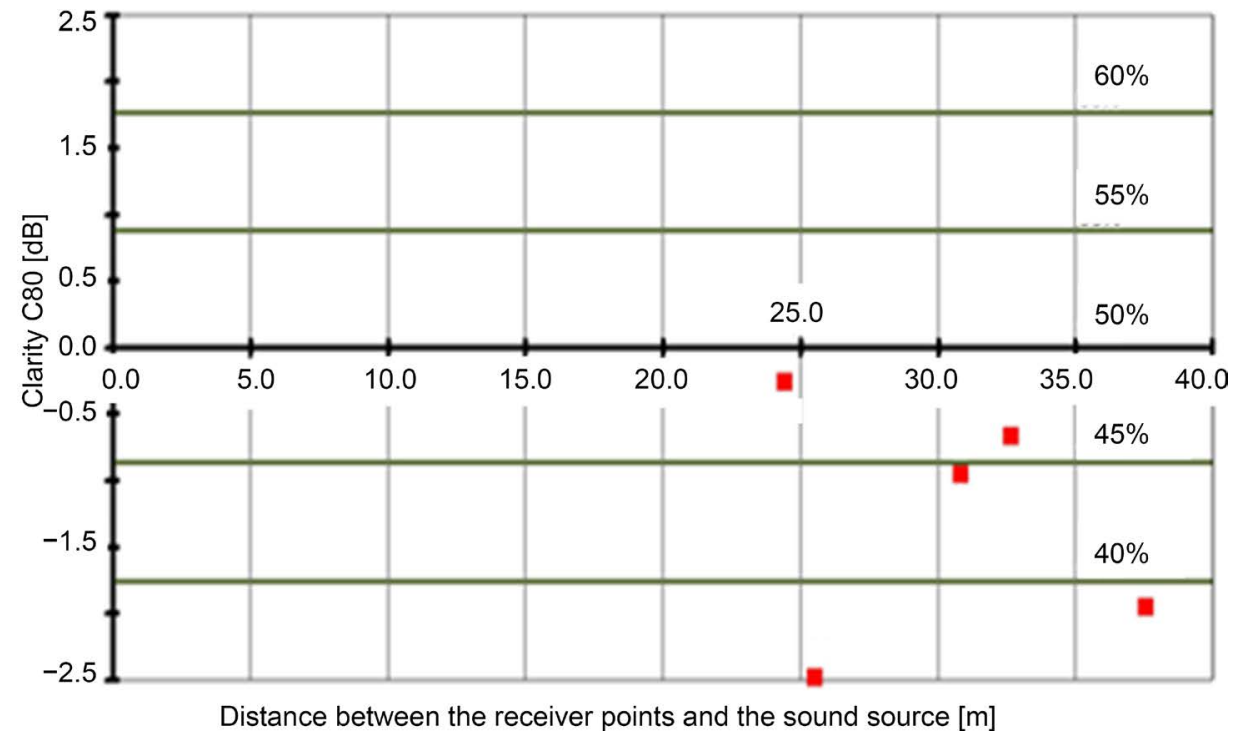

Figure 17. Distribution in the subarea UNDER THE MEZZANINE of the parameter C80 [dB] as a function of the distance $[\mathrm{m}]$ between the receiver points and the sound source.

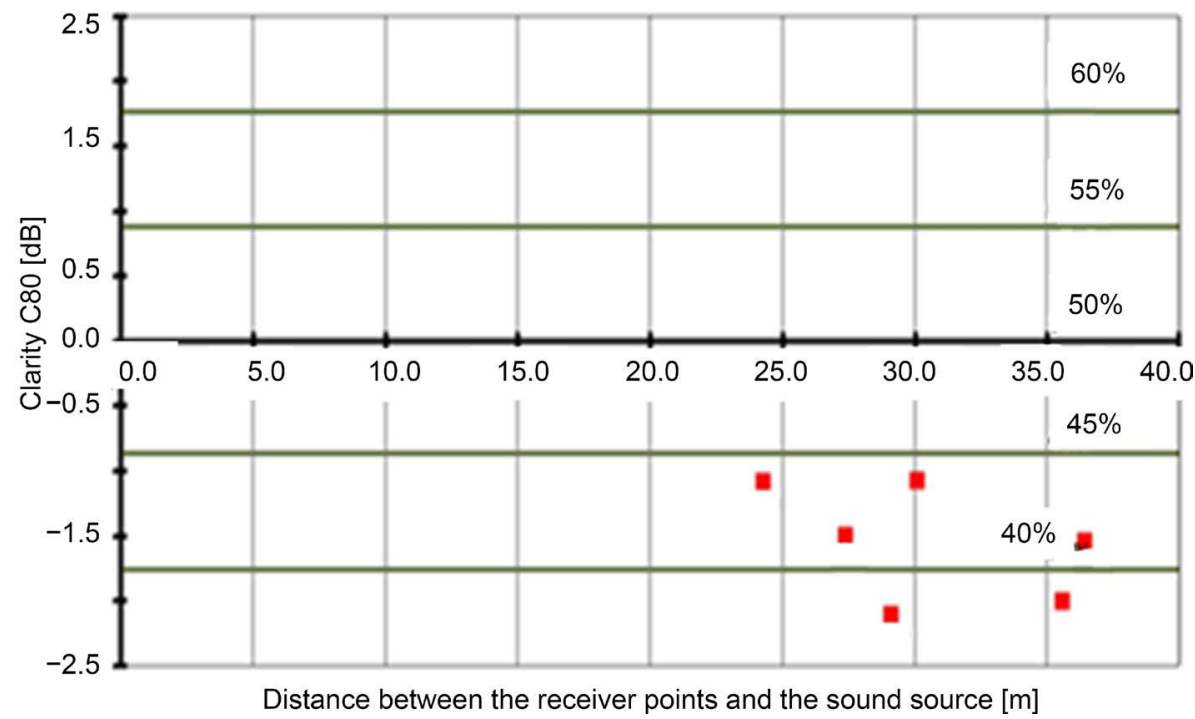

Figure 18. Distribution in the subarea ABOVE THE MEZZANINE of the parameter C80 [dB] as a function of the distance $[\mathrm{m}]$ between the receiver points and the sound source. 


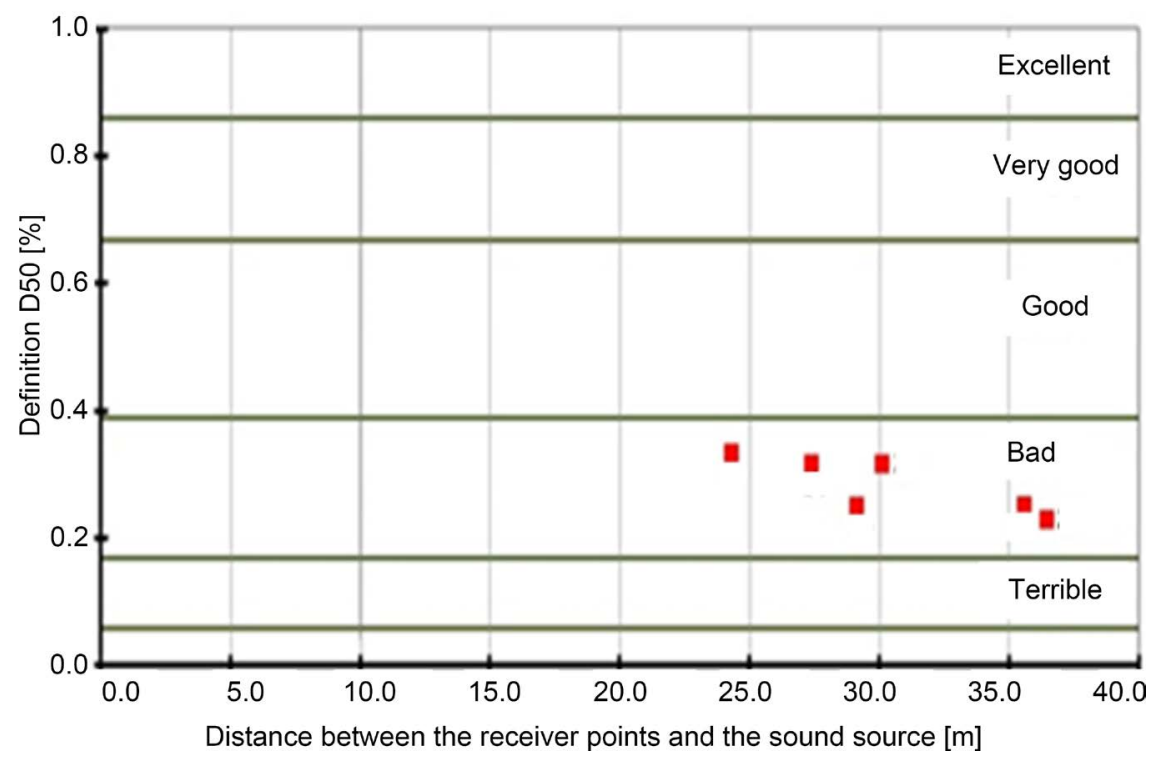

Figure 19. Distribution in the subarea ABOVE THE MEZZANINE of the parameter D50 [\%] as a function of the distance $[\mathrm{m}]$ between the receiver points and the sound source. The graph indicates the range of values proposed by Marshall [15].

minor difference between the measured value and the optimal value recommended by the Brazilian standard NBR 12,179 [16], the church presents low acoustic quality in terms of speech intelligibility and quality of music reproduction.

The values measured for Definition, D50, indicate that most of the analyzed points show values classified as "Bad", according to Marshall [15], for speech intelligibility, which is translated by difficulty in understanding the rendition of sermons. As for the quality of the environment for music performances the profile of the program used in the church-Pop Rock-proved to be even more inadequate, with values of Clarity, C80, never reaching the lowest value recommended by Marshall, i.e., C80 $=7 \mathrm{~dB}$, keeping in mind what was stated earlier in this article, i.e., that this evangelical church uses only the "Pop Rock" music genre.

\section{Conclusions}

From the acoustic/ergonomic point of view, this creates a deleterious working environment for priests and pastors, as well as an environment lacking in speech intelligibility for the listeners. In the specific case of priests/pastors, an environment with low acoustic quality in terms of speech intelligibility will force them to speak louder, which may lead to vocal fatigue.

This paper demonstrates that although the measured reverberation time and the recommended optimum value are almost the same, i.e., measured: $1.93 \mathrm{~s}$ and recommended: $1.8 \mathrm{~s}$, the other parameters analyzed here, D50 and C80, are completely outside the recommendations indicated in the literature used as reference, i.e., Marshall's paper [15]. Therefore, these acoustic descriptors should be included in the design of environments such as that of the church valuated here. It should be kept in mind that 
only the Pop Rock music genre is performed in this church, which, according to Marshall, should have C80 values ranging from 7 to $18 \mathrm{~dB}$. The measured values lie far outside of this range. The same applies to Definition, D50, most of whose measured values are classified as "Bad", i.e., between 0.17 and $0.39 \mathrm{~dB}$, according to Table 6 .

These churches should review the music genre they use in order to improve their overall acoustic conditions.

\section{Acknowledgements}

The authors gratefully acknowledge the financial support of the Brazilian Government, through the National Council for Scientific and Technological Development-CNPq, and the German Government, through the German Academic Exchange Service-DAAD, which enabled the purchase of the equipment and software used in this study.

\section{References}

[1] Jones, D.R. (2010) Sound of Worship-A Handbook of Acoustical and Sound System Design for the Church. Focal Press, Waltham.

[2] (2006) Igreja: Espaço Sagrado Reorganizador do Mundo [The Church: The World's Sacred Reorganizing Space]. Caderno CERU n 17 USP, São Paulo. (In Portuguese)

[3] Paoletti, D.A. (2011) What's So Special (Acoustically) about a Cathedral? 3rd Architecture, Culture and Spirituality Symposium, Focal Press, Waltham, 1-12.

[4] Barber, J. (2006) Luther and Calvin on Music and Worship. Reformed Perspectives Magazine, 8, June 25 to July 1.

[5] St-Onge, C.P. (2003) Music, Worship and Martin Luther. Concordia Theological Seminary, Fort Wayne.

[6] Berardi, U.A. (2012) Double Synthetic Index to Evaluate the Acoustics of Churches. Archives of Acoustics, 37, 521-528. http://dx.doi.org/10.2478/v10168-012-0050-3

[7] Cirillo, E. and Martellota, F. (2006) Worship Acoustics and Architecture. Multi-Science Publishing Co. LTD., Brentwood.

[8] Fleisher, D. (2009) Acoustical Considerations for St. Clare of Assisi's New Church. Envision Church-Georgetown University Center for Liturgy, Washington DC.

[9] Diocese of Columbus (2003) Acoustics for Church and Chapels-A Summary of Concerns, Guiding Principles and Recommendations for Acoustics for the Construction and Renovation of Worship Spaces. The Catholic Diocese of Columbus, Columbus.

[10] Fasold, W. and Veres, E. (2003) Schallschutz + Raumakustik in der Praxis. Verlagfür Bauwesen, Berlin. (In German)

[11] Meyer, J. (2003) Kirchenakustik. Verlag Erwin Bochinsky GmbH \& Co. KG, Frankfurt am Main. (In German)

[12] International Organization for Standardization (2009) ISO 3382-1: Acoustics-Measurement of Room Acoustic Parameters-Part 1: Performance Spaces. Switzerland.

[13] Harris, C.M. (1994) Noise Control in Buildings. McGraw-Hill Inc., New York.

[14] Beranek, L. (1996) Acoustics and Musical Qualities. Journal of the Acoustical Society of America, 99, 2647-2652. http://dx.doi.org/10.1121/1.414808

[15] Marshall, L.G. (1994) An Acoustics Measurement Program for Evaluating Auditoriums Based on the Early/Late Sound Energy Ratio. Journal of the Acoustical Society of America, 
96, 2251-2261. http://dx.doi.org/10.1121/1.410097

[16] Associação Brasileira de Normas Técnicas (1992) NBR 12179: Tratamento acústico em recintos fechados: Procedimento [Brazilian Association of Technical Standards. NBR 12179: Acoustic Treatment of Indoor Spaces: Procedure]. Rio de Janeiro. (In Portuguese)

[17] Silva, L.F. and Cabral, R. (2011) Noise Exposure Levels of Priests and Worshippers in Protestant Churches. International Journal of Occupational Safety and Ergonomics (JOSE), 17, 79-86. http://dx.doi.org/10.1080/10803548.2011.11076872

Submit or recommend next manuscript to SCIRP and we will provide best service for you:

Accepting pre-submission inquiries through Email, Facebook, LinkedIn, Twitter, etc.

A wide selection of journals (inclusive of 9 subjects, more than 200 journals)

Providing 24-hour high-quality service

User-friendly online submission system

Fair and swift peer-review system

Efficient typesetting and proofreading procedure

Display of the result of downloads and visits, as well as the number of cited articles

Maximum dissemination of your research work

Submit your manuscript at: http://papersubmission.scirp.org/ 